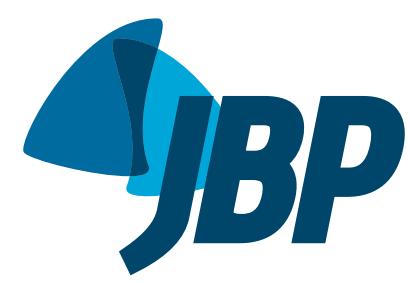

1. Laboratório do Sono e Coração, ProntoSocorro Cardiológico de Pernambuco - PROCAPE - Universidade de Pernambuco, Recife (PE) Brasi

2. Hospital Metropolitano Sul Dom Helder Câmara, Instituto de Medicina Integral Professor Fernando Figueira - IMIP Hospitalar - Recife (PE) Brasil.

Submitted: 23 May 2016

Accepted: 31 October 2016.

Study carried out in the Laboratório do Sono e Coração, Pronto-Socorro Cardiológico de Pernambuco - PROCAPE - Universidade de Pernambuco, and at the Hospital Metropolitano Sul Dom Helder Câmara, Instituto de Medicina Integra Professor Fernando Figueira - IMIP Hospitalar - Recife (PE) Brasil

\section{The role of physical exercise in obstructive sleep apnea}

\author{
Flávio Maciel Dias de Andrade ${ }^{1,2}$, Rodrigo Pinto Pedrosa ${ }^{1,2}$
}

\begin{abstract}
Obstructive sleep apnea (OSA) is a common clinical condition, with a variable and underestimated prevalence. OSA is the main condition associated with secondary systemic arterial hypertension, as well as with atrial fibrillation, stroke, and coronary artery disease, greatly increasing cardiovascular morbidity and mortality. Treatment with continuous positive airway pressure is not tolerated by all OSA patients and is often not suitable in cases of mild OSA. Hence, alternative methods to treat OSA and its cardiovascular consequences are needed. In OSA patients, regular physical exercise has beneficial effects other than weight loss, although the mechanisms of those effects remain unclear. In this population, physiological adaptations due to physical exercise include increases in upper airway dilator muscle tone and in slow-wave sleep time; and decreases in fluid accumulation in the neck, systemic inflammatory response, and body weight. The major benefits of exercise programs for OSA patients include reducing the severity of the condition and daytime sleepiness, as well as increasing sleep efficiency and maximum oxygen consumption. There are few studies that evaluated the role of physical exercise alone for OSA treatment, and their protocols are quite diverse. However, aerobic exercise, alone or combined with resistance training, is a common point among the studies. In this review, the major studies and mechanisms involved in OSA treatment by means of physical exercise are presented. In addition to systemic clinical benefits provided by physical exercise, OSA patients involved in a regular, predominantly aerobic, exercise program have shown a reduction in disease severity and in daytime sleepiness, as well as an increase in sleep efficiency and in peak oxygen consumption, regardless of weight loss.
\end{abstract}

Keywords: Exercise therapy; Sleep apnea, obstructive; Cardiovascular diseases.

\section{INTRODUCTION}

Obstructive sleep apnea (OSA) is a very common but underdiagnosed clinical condition and is associated with the development or worsening of a number of clinical conditions. ${ }^{(1-7)}$ In a study conducted by Tufik et al. in the city of São Paulo, Brazil, in 2010,(5) the prevalence of OSA in a general population in the 20- to 80 -year age bracket was found to be $32.8 \%$, being $40.6 \%$ in males and $26.2 \%$ in females.

Epidemiological data suggest that regular physical exercise has beneficial effects other than weight loss in OSA patients; however, the mechanisms of those effects remain unclear.

\section{OSA DEFINITION, CLASSIFICATION, AND RISK FACTORS}

OSA is characterized by upper airway obstruction during sleep, resulting in recurrent hypoxia, hypercapnia, and arousals. ${ }^{(8-11)}$ It is diagnosed by polysomnography, which is a test that allows the calculation of the apnea-hypopnea index (AHI), i.e., the ratio of the total number of apneas and hypopneas to total sleep time. ${ }^{(2,8,9)}$ The severity of OSA is determined by the AHI: 5.0-14.9 events/h, mild
OSA; $15-30$ events/h, moderate OSA; and > 30 events/h, severe OSA. ${ }^{(2,8)}$

The etiology of OSA is multifactorial, including anatomical changes, neuromuscular factors, and genetic predisposition. The major risk factors for OSA are shown in Chart 1. ${ }^{(8-12)}$

\section{CLINICAL MANIFESTATIONS OF OSA}

Recurrent apnea, hypoxia, and hypercapnia, as well as sleep fragmentation (microarousals), together with increased negative intrathoracic pressure-which results from increased inspiratory muscle work in order to reopen the collapsed airways-result in impaired central nervous system, cardiovascular system, and metabolic function. ${ }^{(8,9,11-13)}$ Excessive daytime sleepiness, nocturia, morning headache, decreased libido, attention deficit, impaired concentration, neurocognitive impairment, irritability, and depression are common in patients with OSA and greatly reduce their work efficiency and quality of life. ${ }^{(10,11)}$

OSA is associated with a variety of cardiovascular disorders, including systemic arterial hypertension (SAH), myocardial ischemia, cardiac arrhythmia, stroke, and

Correspondence to:

Rodrigo Pinto Pedrosa. Laboratório do Sono e Coração, Pronto-Socorro Cardiológico de Pernambuco (PROCAPE), Rua dos Palmares, SN, Recife, PE, Brasil.

Tel./Fax: 5581 3181-7179. E-mail: rppedrosa@terra.com.br

Financial support: This study received financial support from the Brazilian Conselho Nacional de Desenvolvimento Cientifico e Tecnológico ICNPq, National Council for

Scientific and Technological Development). 
Chart 1. Risk factors for obstructive sleep apnea. ${ }^{(8-12)}$

$\begin{array}{cc}\text { Snoring } & \text { Retrognathia or micrognathia } \\ \text { Male gender } & \text { Nasal obstruction } \\ \text { Age }>50 \text { years } & \text { Hyperplasia of the tonsils and adenoids } \\ \text { Menopause } & \text { Macroglossia } \\ \text { Obesity } & \text { Collapse of the soft palate }\end{array}$

increased arterial stiffness. ${ }^{(14)}$ In patients with OSA, the most common cardiovascular comorbidity is $\mathrm{SAH}$, and the relationship between SAH and OSA was first described 30 years ago. The prevalence and severity of $\mathrm{SAH}$ increase linearly with the increase in OSA severity. OSA treatment can reduce blood pressure. $(8,9,11-13,15)$

Recently, OSA has been associated with a systemic inflammatory response, resulting in atherosclerosis, insulin resistance, type 2 diabetes, and lipid profile changes, thus greatly increasing morbidity and mortality in patients with untreated OSA. Figure 1 shows the pathophysiology of the effects of OSA on the cardiovascular system. ${ }^{(10)}$

\section{THERAPEUTIC STRATEGIES FOR OSA}

Continuous positive airway pressure (CPAP) is typically the treatment of choice for OSA. It maintains a positive pharyngeal transmural pressure and increases end-expiratory lung volume, contributing to the maintenance of an open airway. ${ }^{(2,10)}$ The aforementioned benefits were first reported by Sullivan et al. in 1981. ${ }^{(16)}$

According to the American Academy of Sleep Medicine, CPAP should be the first-line treatment for moderate to severe OSA (AHI > 15 events/h). The clinical decision to prescribe CPAP is based on the possibility of symptom relief and cardiovascular protection. Although CPAP is effective, it might not be tolerated by some patients. Adherence to CPAP therapy is highest in patients who snore heavily and have excessive daytime sleepiness. ${ }^{(2,17-24)}$

Sleep hygiene and changes in lifestyle habits, including weight loss, discontinuation or replacement of drugs that directly interfere with upper airway muscle function (benzodiazepines, barbiturates, and narcotics), reducing alcohol consumption (especially during the evening), smoking cessation, regular physical activity, and changing body position during sleep (avoiding the supine position) should always be encouraged in the treatment of OSA. ${ }^{(2,17-24)}$

The use of oral appliances is recommended in order to prevent the oropharynx and base of the tongue from collapsing during sleep. Mandibular repositioning or mandibular advancement splints are currently the most commonly used devices. They are indicated for the treatment of mild OSA and primary snoring. They can also be used in individuals who do not tolerate or would rather not use CPAP. Their use is contraindicated in patients with a predominance of central apneas, in those with active periodontal disease, and in those with temporomandibular joint dysfunction. $(2,17-24)$
Although surgical procedures were widely used in the treatment of OSA in the recent past, they are no longer used, because of symptom recurrence after a few months. In addition to being used in cases of significant facial changes and in young individuals with significant tonsillar hypertrophy, surgery has been used in order to improve nasal breathing for the use of a CPAP mask. ${ }^{(2,17-24)}$

\section{EXERCISE-RELATED PHYSIOLOGICAL ADAPTATIONS IN OSA PATIENTS}

Recent studies have focused on exercise programs for patients with OSA because they constitute a low-cost, easy-to-use treatment modality and have been shown to be effective in mitigating several harmful consequences of OSA, including cardiovascular disorders, glucose intolerance, and fatigue. ${ }^{(25-27)}$

The mechanisms whereby physical exercise attenuates OSA have yet to be well defined. It was long believed that the beneficial effects of physical exercise on patients with OSA were related to a reduction in body weight; however, experimental and clinical studies have shown that the benefits of exercise are independent of weight loss. ${ }^{(20,27-29)}$ Several hypotheses have been proposed to explain the beneficial effects of physical exercise on patients with OSA.

\section{Increased upper airway dilator muscle tone}

Maintenance of airway patency requires the coordinated activity of upper airway and thoracic respiratory muscles. ${ }^{(30,31)}$ Inspiratory muscle contraction results in a subatmospheric pressure gradient that allows the air to enter the respiratory system and predisposes to pharyngeal collapse. This trend toward pharyngeal collapse is compensated by the activation and contraction of several upper airway dilator muscles, such as the sternohyoid and omohyoid muscles, and pharyngeal lumen regulators, such as the genioglossus and digastric muscles. ${ }^{(32)}$

The effects of exercise on the characteristics and activity of the aforementioned muscles remain unclear. During physical activity, the respiratory muscles, particularly the diaphragm, work at an increased rate. This leads to metabolic and structural adaptations that improve fatigue resistance. On the basis of the knowledge that exercise increases respiratory muscle recruitment, it seems plausible that endurance exercise might result in increased upper airway muscle activation to increase upper airway diameter, reduce airway resistance, and oppose pharyngeal collapse during sleep. ${ }^{(32)}$ 


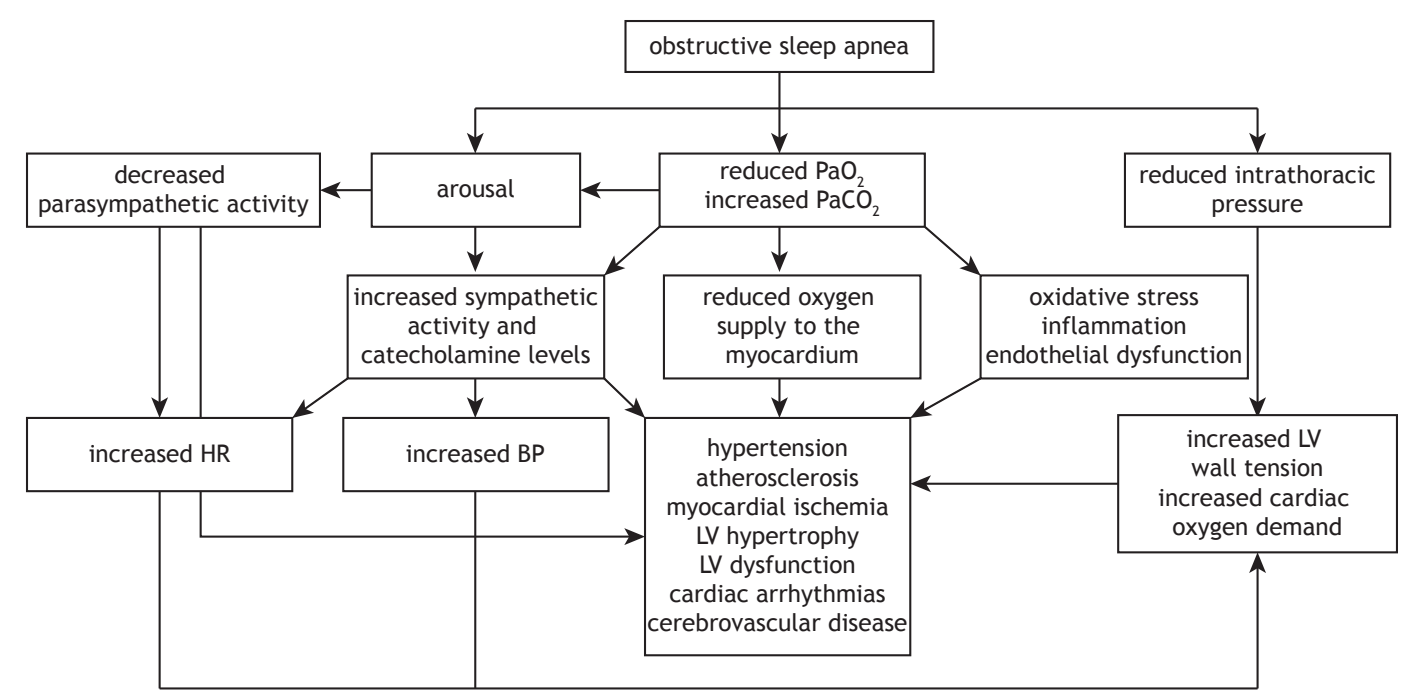

Figure 1. Pathophysiology of the effects of obstructive sleep apnea on the cardiovascular system. Adapted from Bradley \& Floras, 2009.(10) BP: blood pressure; and LV: left ventricular.

Haxhiu et al. ${ }^{(33)}$ and Hussain et al. ${ }^{(34)}$ used similar methods for electrically stimulating the gastrocnemius muscle nerve of anesthetized dogs and noted an acute and significant increase in the tone and peak electromyographic activity of the genioglossus muscle, suggesting that greater activation of the lower limb muscles, such as occurs during physical activity, can result in greater activation of the upper airway dilator muscles, thus counterbalancing the increase in transpulmonary pressure gradient resulting from increased respiratory muscle activity.

Subsequently, Vincent et al. ${ }^{(32)}$ evaluated 32 rats, which were divided into three groups: one group of sedentary rats $(n=10)$; one group of rats undergoing endurance exercise $(n=10)$; and one group of rats undergoing acute exercise $(n=12)$. The authors found that a 12-week treadmill exercise protocol (4 days/week, $90 \mathrm{~min} /$ day, at approximately $75 \%$ of maximal oxygen consumption) increased oxidative capacity, antioxidant activity, and type I muscle fiber content, as well as decreasing lipid peroxidation and type IIb muscle fiber content of the digastric and sternohyoid muscles. No such changes were noted in the genioglossus and omohyoid muscles.

In light of the current literature, the true role of physical exercise in improving upper airway dilator muscle performance in humans remains unclear. In this sense, this physiological effect of exercise on patients with OSA has yet to be confirmed.

\section{Reduced fluid accumulation in the neck}

Sedentary lifestyle and decreased ambulation are associated with fluid retention in the legs, given the central role of leg muscles in venous fluid dynamics. During sleep, the recumbent position contributes to fluid displacement to and accumulation in the neck, which increases laryngeal compression. This mechanism can increase the severity of OSA, given that most
OSA patients have excessive daytime sleepiness and a sedentary lifestyle. ${ }^{(35-39)}$

Redolfi et al. (40) evaluated the relationship between overnight rostral fluid shift from the legs and OSA severity in 23 nonobese males. Associations were found between reduced leg fluid volume and increased neck circumference $(r=-0.792 ; p=0.001)$, between increased overnight rostral fluid shift from the legs and increased AHI ( $\left.r^{2}=0.643 ; p=0.001\right)$, and between increased time spent sitting daily and increased rostral fluid shift $\left(r^{2}=0.346 ; p=0.003\right)$. This last finding emphasizes the role of sedentary behavior in fluid accumulation in the neck during sleep.

The role that fluid accumulation in the neck plays in the development and worsening of OSA is more evident in patients with hypervolemia, especially those with chronic kidney disease, heart failure, and resistant hypertension, which are clinical conditions that are independently associated with reduced cardiorespiratory efficiency and muscular endurance, ${ }^{(37)}$ resulting in a vicious cycle of sorts in the genesis of OSA (Figure 2).

White et al. ${ }^{(41)}$ evaluated the effect of compression stockings on OSA severity in 22 individuals with leg edema, who were compared with a control group ( $\mathrm{n}$ = 23). The AHI decreased significantly in the group of patients who wore compression stockings, in association with reduced nocturnal fluid shift from the legs and a significant increase in morning upper-airway cross-sectional area, neck fluid volume having remained unchanged overnight.

The real role of regular physical exercise in improving leg fluid dynamics and, consequently, OSA has yet to be clarified. Mendelson et al. ${ }^{(42)}$ evaluated the effect of physical exercise on OSA and central sleep apnea in 34 individuals with coronary artery disease undergoing 4 weeks of aerobic exercise training, those 34 individuals being compared with a group of controls. All participants underwent polysomnography 
at baseline and follow-up, the following being measured before and after sleep: leg fluid volume; neck fluid volume; thoracic fluid volume; and upper-airway cross-sectional area. The AHI decreased significantly in the exercise group, in association with a significant reduction in the overnight change in leg fluid volume and a significant increase in the overnight change in upper-airway cross-sectional area.

In another study, physical activity was found to have improved OSA severity in patients with heart failure; however, patients with fluid overload, as is the case of heart failure patients, are more likely to benefit from exercise than are those without hypervolemia. ${ }^{(39)}$

\section{Increased slow-wave sleep}

Normal sleep is divided into rapid eye movement (REM) sleep and non-rapid eye movement (NREM) sleep. Physiologically, REM sleep accounts for approximately $25 \%$ of total sleep time, being characterized by rapid, low-amplitude brain activity; episodes of REM; ventilatory instability; and hypotonic muscles, including those responsible for upper airway patency. Currently, NREM sleep is divided into stages 1,2 , and 3 , stage 3 being designated slow-wave sleep and being characterized by a deeper sleep and an increased arousal threshold. ${ }^{(43)}$

Ratnavadivel et al. ${ }^{(44)}$ evaluated 253 individuals and found that it took those with OSA longer to achieve slow-wave sleep, OSA patients also having decreased slow-wave sleep, increased daytime sleepiness, and an increased AHI. McSharry et al. (45) found increased genioglossus single motor unit activity during slow-wave sleep and proposed that this increased activity makes the airway more stable and resistant to collapse.

The first reports of the effects of exercise on sleep patterns date from 1970. Heinzelmann and Bagley(46) reported that individuals who participated in an 18-month exercise program during which they exercised for $1 \mathrm{~h}$ three times a week had a more relaxing and restorative sleep.

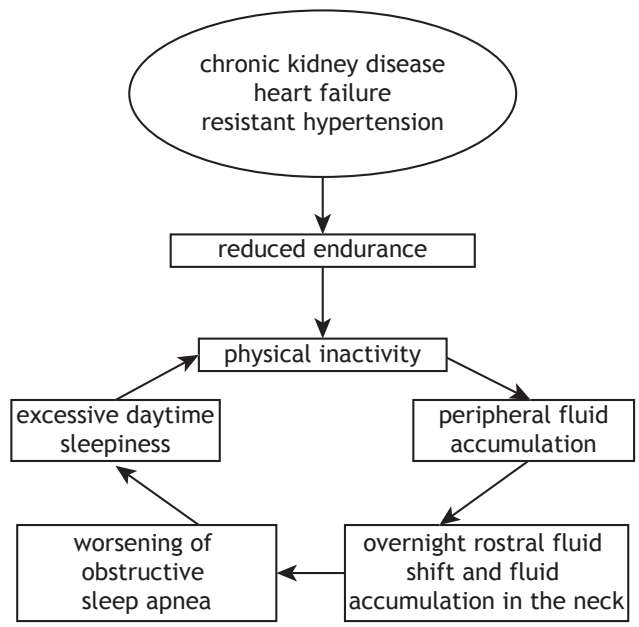

Figure 2. Interrelationship between chronic diseases resulting in hypervolemia and worsening of obstructive sleep apnea.
Exercise increases body temperature and can therefore facilitate the onset of sleep by activating heat-dissipating processes and hypothalamus-controlled sleep-inducing mechanisms. The theories of body energy conservation and organ function restoration indicate that there is a relationship between increased energy expenditure and increased stage 3 NREM sleep. ${ }^{(47)}$

Previous studies have shown sleep pattern changes in individuals undergoing exercise programs, including increased slow-wave sleep, decreased REM sleep, and increased latency to REM sleep. ${ }^{(48,49)}$

Ueno et al.(26) evaluated patients with functional class I-III heart failure and OSA, central sleep apnea, or no sleep apnea. The patients underwent a 4-month exercise program consisting of three 60 -min sessions per week divided into muscle stretching and cycle ergometry, the intensity of which was set at $10 \%$ below the respiratory compensation point obtained by cardiopulmonary exercise testing. The authors found an increase in stage 3 NREM sleep. ${ }^{(26)}$

Recently, Kredlow et al. ${ }^{(50)}$ performed a meta-analysis of the effects of acute and regular exercise on sleep quality and found that exercise can improve subjective perception and objective parameters of sleep (including total sleep time, sleep efficiency, and duration of slow-wave sleep).

\section{Reduced body weight}

Physical exercise can reduce OSA severity by reducing body weight and abdominal fat. Previous data have shown that a $10 \%$ reduction in the body mass index (BMI) is associated with a $30 \%$ reduction in the AHI. ${ }^{(21,51)}$ Dobrosielski et al. ${ }^{(52)}$ found a reduced $\mathrm{AHI}$ associated with a reduced BMI in OSA patients undergoing an aerobic exercise program and following a calorie-restricted diet.

Barnes et al. ${ }^{(53)}$ evaluated 21 OSA patients undergoing a program combining a very-low-energy diet and aerobic and resistance exercise and found a significant reduction in the BMI and Epworth Sleepiness Scale score in those with mild to moderate OSA, but no significant changes in the AHI. These results suggest that there is a need for randomized controlled studies aimed at determining the relationship among physical exercise, body weight reduction, and OSA severity.

\section{Reduced systemic inflammatory response}

Adipose tissue, particularly abdominal fat, is rich in inflammatory cytokines. OSA can modulate the expression and release of inflammatory mediators from visceral fat and other tissues. Independently of obesity, OSA patients have been found to have elevated levels of C-reactive protein, TNF, and IL-6, which are associated with sleepiness, fatigue, and various metabolic and cardiovascular complications. ${ }^{(54)}$

Adiponectin is a protein that is secreted exclusively by white adipose tissue and has anti-inflammatory and antiatherosclerotic effects; in patients with OSA, serum adiponectin concentrations are reduced, increasing their risk of cardiovascular disease. ${ }^{(54)}$ 
Chart 2. Characteristics of the exercise programs.

\begin{tabular}{|c|c|c|c|}
\hline Authors & Participants & Characteristics of the exercise program & Results \\
\hline $\begin{array}{l}\text { Norman } \\
\text { et al. }{ }^{(56)}\end{array}$ & $\begin{array}{l}9 \text { patients } \\
\text { with mild to } \\
\text { moderate OSA }\end{array}$ & 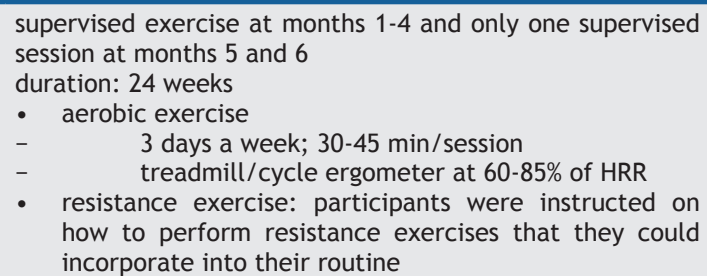 & $\begin{array}{c}\text { reduced } \mathrm{AHI} \text { and } \mathrm{BMI} ; \\
\text { improved aerobic } \\
\text { capacity and quality of } \\
\text { life }\end{array}$ \\
\hline Barnes et al. ${ }^{(53)}$ & $\begin{array}{l}21 \text { patients } \\
\text { with mild to } \\
\text { severe AHI }\end{array}$ & $\begin{array}{l}\text { supervised exercise at weeks } 1-8 \text {; from week } 9 \text { onward, only } \\
\text { one supervised session } \\
\begin{array}{ll}12 . & \text { resistance exercise } \\
- & \text { duration: } 16 \text { weeks } \\
- & 3 \text { days/week at } 80 \% \text { of maximal resistance } \\
- & 7 \text { different muscle groups; dumbbells; } 8-12 \\
\text { repetitions } \\
13 . \quad \text { aerobic exercise } \\
- & \text { beginning at week } 5 \text { of the resistance exercise } \\
\text { program } & \\
- & \text { duration: } 24 \text { weeks } \\
- & 5 \text { days/week; } 40 \text { min/session } \\
- & \text { walking, cycling, and jogging at } 80 \% \text { of } \mathrm{VO}_{2 \text { peak }}\end{array}\end{array}$ & $\begin{array}{l}\text { reduced body weight } \\
\text { and daytime sleepiness; } \\
\text { improved cardiometabolic } \\
\text { outcomes (MAP, } \\
\text { cholesterol levels, } \\
\text { triglyceride levels, } \\
\text { C-reactive protein levels, } \\
\text { insulin levels, GGT levels, } \\
\text { and } \mathrm{VO}_{\text {2peak }} \text { ) and quality } \\
\text { of life }\end{array}$ \\
\hline Kline et al. ${ }^{(57)}$ & $\begin{array}{c}43 \text { patients } \\
\text { with moderate } \\
\text { OSA }\end{array}$ & 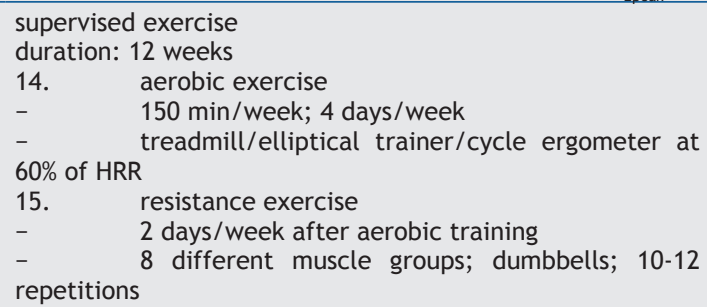 & $\begin{array}{l}\text { reduced } \mathrm{AHI} \text { and oxygen } \\
\text { desaturation index; no } \\
\text { changes in the BMI }\end{array}$ \\
\hline Sengul et al. ${ }^{(28)}$ & $\begin{array}{l}20 \text { patients } \\
\text { with mild to } \\
\text { moderate OSA }\end{array}$ & $\begin{array}{ll}\text { supervised exercise } \\
\text { duration: } & 12 \text { weeks } \\
16 . & \text { aerobic exercise } \\
- & 3 \text { days } / \text { week; } 60-90 \mathrm{~min} / \mathrm{session} \\
- & \text { treadmill/cycle ergometer at } 60-70 \% \text { of } \mathrm{VO}_{2 \text { peak }} \\
17 . & \text { breathing exercises } \\
- & 3 \text { days } / \text { week; } 15-30 \mathrm{~min} / \mathrm{session}\end{array}$ & $\begin{array}{c}\text { Reduced AHI; improved } \\
\text { exercise capacity, sleep } \\
\text { quality, and quality of } \\
\text { life; no changes in the } \\
\text { BMI }\end{array}$ \\
\hline $\begin{array}{l}\text { Servantes } \\
\text { et al. }{ }^{(58)}\end{array}$ & $\begin{array}{l}50 \text { patients } \\
\text { with heart } \\
\text { failure and } \\
\text { OSA }\end{array}$ & 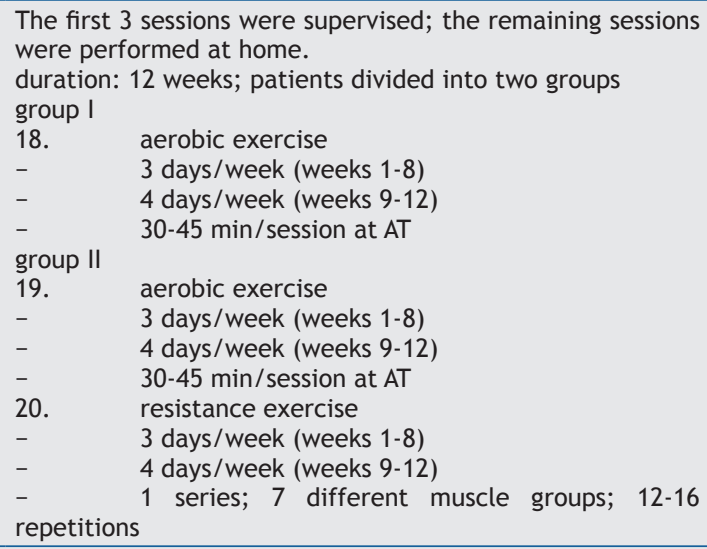 & $\begin{array}{l}\text { increased exercise } \\
\text { capacity, muscle } \\
\text { strength, and muscle } \\
\text { resistance; reduced } \mathrm{AHI}\end{array}$ \\
\hline $\begin{array}{l}\text { Ackel-D'elia } \\
\text { et al.(60) }\end{array}$ & $\begin{array}{l}32 \text { patients } \\
\text { with moderate } \\
\text { to severe OSA } \\
\text { and ESS score } \\
>9\end{array}$ & $\begin{array}{l}\text { supervised exercise } \\
\text { duration: } 2 \text { months } \\
-\quad \text { aerobic exercise } \\
-\quad \quad 3 \text { days } / \text { week; } 40 \mathrm{~min} / \text { session } \\
-\quad \text { treadmill at } 85 \% \text { of AT }\end{array}$ & $\begin{array}{l}\text { reduced sleepiness, } \\
\text { tension, and fatigue; } \\
\text { increased physical } \\
\text { functioning and vitality }\end{array}$ \\
\hline Schütz et al. ${ }^{(61)}$ & $\begin{array}{c}25 \text { patients } \\
\text { with moderate } \\
\text { to severe OSA }\end{array}$ & $\begin{array}{l}\text { supervised exercise } \\
\text { aerobic and resistance exercise } \\
\text { duration: } 2 \text { months } \\
3 \text { days/week; } 60 \mathrm{~min} / \text { session } \\
\text { The exercise protocol was not described. }\end{array}$ & $\begin{array}{c}\text { reduced daytime } \\
\text { sleepiness, LDL levels, } \\
\text { and triglyceride levels }\end{array}$ \\
\hline
\end{tabular}

OSA: obstructive sleep apnea; HRR: heart rate reserve; AHI: apnea-hypopnea index; BMI: body mass index; MAP: mean arterial pressure; $\mathrm{VO}_{2 \text { eak }}$ : peak oxygen consumption; GGT: gamma-glutamyltransferase; AT: anaerobic threshold; and ESS: Epworth Sleepiness Scale. 
Studies have shown that regular exercise has an anti-inflammatory effect, especially in obese patients; however, the impact of this treatment modality on the inflammatory response of individuals with OSA remains unclear. ${ }^{(54)}$ In a recent study, Cavagnolli et al. ${ }^{(55)}$ evaluated the effects of a 2-month aerobic exercise program on 20 nonobese adult males, 10 of whom had OSA; the authors found that C-reactive protein levels were similar between the control group and the OSA group, as well as finding a less than significant reduction in C-reactive protein levels and the $\mathrm{AHI}$ after the exercise program.

\section{CLINICAL BENEFITS OF EXERCISE IN THE TREATMENT OF OSA}

In a recent meta-analysis of five studies, Iftikhar et al. ${ }^{(7)}$ found significant reductions in the $\mathrm{AHI}$ and daytime sleepiness, as well as increases in sleep efficiency and peak oxygen consumption $\left(\mathrm{VO}_{2 \text { peak }}\right)$, in adult patients with OSA. ${ }^{(28,56-58)}$ The authors ${ }^{(7)}$ found that OSA patients undergoing regular exercise had a $32 \%$ reduction in the AHI (a reduction of 6.27 events/h) and a $28 \%$ reduction in daytime sleepiness, as well as a $5.8 \%$ increase in sleep efficiency and a $17.65 \%$ increase in $\mathrm{VO}_{2 \text { peak }}$, having found no significant reduction in the $\mathrm{BMI}$ $\left(\mathrm{VO}_{2 \text { peak }}=-1.37 ; 95 \% \mathrm{CI}:-2.81\right.$ to $0.07 ; \mathrm{p}=0.06$, $\left.\mathrm{I}^{2}=76.92 \%\right)$. Another important point is that even if exercise has no significant impact on OSA severity, indirect benefits of exercise include decreased blood pressure, improved metabolic profile, and reduced overall cardiovascular risk. More recently, Aiello et al. ${ }^{(59)}$ performed a meta-analysis of nine studies and confirmed the findings of Iftikhar et al., (7) having found a reduction in the $\mathrm{AHI}$ and in daytime sleepiness after exercise as the sole treatment for OSA.

There is a lack of studies evaluating the role of exercise as the sole treatment for OSA. In addition, there are differences across studies regarding exercise protocols; however, aerobic exercise (either in isolation or in combination with resistance exercise) has been used in all studies. The main characteristics of the exercise programs used in seven randomized controlled studies are shown in Chart 2. $(28,53,56-58,60,61)$

\section{FINAL CONSIDERATIONS}

A condition that affects several organ systems, OSA significantly increases morbidity and mortality. The most common therapeutic strategies (i.e., CPAP, oral appliances, and corrective upper airway surgery) are sometimes not tolerated by patients. In this context, physical exercise is a therapeutic alternative for patients with OSA, because it is simple and inexpensive, as well as having systemic benefits.

Exercise-related physiological adaptations in OSA patients include increased upper airway dilator muscle tone, reduced fluid accumulation in the neck, increased slow-wave sleep (stage 3 NREM sleep), reduced body weight, and reduced systemic inflammatory response.

In addition to conferring systemic clinical benefits, regular, predominantly aerobic, exercise results in reduced OSA severity (a reduced $\mathrm{AHI}$ ), reduced daytime sleepiness, increased sleep efficiency, and increased $\mathrm{VO}_{2 \text { peak }}$ independently of weight loss. Although these findings are encouraging, further studies are needed in order to clarify the true role of physical exercise in the treatment of OSA and its complications.

\section{REFERENCES}

1. Spicuzza L, Caruso D, Di Maria G. Obstructive sleep apnoea syndrome and its management. Ther Adv Chronic Dis. 2015;6(5):273-85. http:// dx.doi.org/10.1177/2040622315590318

2. Naughton MT. Sleep disorders in patients with congestive heart failure. Curr Opin Pulm Med. 2003;9(6):453-8. http://dx.doi org/10.1097/00063198-200311000-00001

3. Lorenzi-Filho G, Genta PR, Pedrosa RP, Drager LF, Martinez D. Cardiovascular consequences of obstructive sleep apnea syndrome [Article in Portuguese]. J Bras Pneumol. 2010;36 Suppl 2:38-42.

4. Punjabi NM. The epidemiology of adult obstructive sleep apnea Proc Am Thorac Soc. 2008;5(2):136-43. http://dx.doi.org/10.1513/ pats.200709-155MG

5. Tufik S, Santos-Silva R, Taddei JA, Bittencourt LR. Obstructive sleep apnea syndrome in the Sao Paulo Epidemiologic Sleep Study. Sleep Med. 2010;11(5):441-6. http://dx.doi.org/10.1016/1. sleep.2009.10.005

6. Pedrosa RP, Drager LF, Gonzaga CC, Sousa MG, de Paula LK, Amaro $A C$, et al. Obstructive sleep apnea: The most common secondary cause of hypertension associated with resistant hypertension. Hypertension. 2011;58(5):811-7. http://dx.doi.org/10.1161/ HYPERTENSIONAHA.111.179788

7. Iftikhar $\mathrm{IH}$, Kline CE, Youngstedt SD. Effects of exercise training on sleep apnea: a meta-analysis. Lung. 2014;192(1):175-84. http:// dx.doi.org/10.1007/s00408-013-9511-3

8. Pham LV, Schwartz AR. The pathogenesis of obstructive sleep apnea. J Thorac Dis. 2015;7(8):1358-72.

9. Jordan AS, McSharry DG, Malhotra A. Adult obstructive sleep apnoea. Lancet. 2014;383(9918):736-47. http://dx.doi.org/10.1016 S0140-6736(13)60734-5
10. Bradley TD, Floras JS. Obstructive sleep apnoea and its cardiovascular consequences. Lancet. 2009;373(9657):82-93. http:// dx.doi.org/10.1016/S0140-6736(08)61622-0

11. Somers VK, White DP, Amin R, Abraham WT, Costa F, Culebras A, et al. Sleep apnea and cardiovascular disease: an American Heart Association/American College of Cardiology Foundation Scientific Statement from the American Heart Association Council for High Blood Pressure Research Professional Education Committee, Council on Clinical Cardiology, Stroke Council, and Council on Cardiovascular Nursing. J Am Coll Cardiol. 2008;52(8):686-717. http:// dx.doi.org/10.1016/j.jacc.2008.05.002

12. Stansbury RC, Strollo PJ. Clinical manifestations of sleep apnea. $J$ Thorac Dis. 2015;7(9):E298-310

13. Lévy P, Ryan S, Oldenburg O, Parati G. Sleep apnoea and the heart. Eur Respir Rev. 2013;22(129):333-52. http://dx.doi org/10.1183/09059180.00004513

14. Pedrosa RP, Barros IM, Drager LF, Bittencourt MS, Medeiros AK, Carvalho LL, et al. OSA is common and independently associated with hypertension and increased arterial stiffness in consecutive perimenopausal women. Chest. 2014;146(1):66-72. http://dx.doi. org/10.1378/chest.14-0097

15. Pedrosa RP, Drager LF, de Paula LK, Amaro AC, Bortolotto LA Lorenzi-Filho G. Effects of OSA treatment on BP in patients with resistant hypertension: a randomized trial. Chest. 2013;144(5):148794. http://dx.doi.org/10.1378/chest.13-0085

16. Sullivan CE, Issa FG, Berthon-Jones M, Eves L. Reversal of obstructive sleep apnoea by continuous positive airway pressure applied through the nares. Lancet. 1981;1(8225):862-5. http://dx.doi. org/10.1016/S0140-6736(81)92140-1 
17. Morgenthaler TI, Kapen S, Lee-Chiong T, Alessi C, Boehlecke B, Brown T, et al. Practice parameters for the medical therapy of obstructive sleep apnea. Sleep. 2006;29(8):1031-5.

18. Sundaram S, Bridgman SA, Lim J, Lasserson TJ. Surgery for obstructive sleep apnoea. Cochrane Database Syst Rev. 2005;(4):CD001004.

19. Smith PL, Gold AR, Meyers DA, Haponik EF, Bleecker ER. Weight loss in mildly to moderately obese patients with obstructive sleep apnea. Ann Intern Med. 1985;103(6 (Pt 1)):850-5. http://dx.doi. org/10.7326/0003-4819-103-6-850

20. Schwartz AR, Gold AR, Schubert N, Stryzak A, Wise RA, Permutt $S$, et al. Effect of weight loss on upper airway collapsibility in obstructive sleep apnea. Am Rev Respir Dis. 1991:144(3 Pt 1):494-8. http://dx.doi.org/10.1164/ajrccm/144.3_Pt_1.494

21. Peppard PE, Young T, Palta M, Dempsey J, Skatrud J. Longitudinal study of moderate weight change and sleep-disordered breathing JAMA. 2000;284(23):3015-21. http://dx.doi.org/10.1001/ jama.284.23.3015

22. Kushida CA, Morgenthaler TI, Littner MR, Alessi CA, Bailey D, Coleman $\mathrm{J} \mathrm{Jr}$, et al. Practice parameters for the treatment of snoring and Obstructive Sleep Apnea with oral appliances: an update for 2005. Sleep. 2006;29(2):240-3.

23. Kushida CA, Littner MR, Hirshkowitz M, Morgenthaler TI, Alessi CA, Bailey $D$, et al. Practice parameters for the use of continuous and bilevel positive airway pressure devices to treat adult patients with sleep-related breathing disorders. Sleep. 2006;29(3):375-80.

24. Bennett LS. Adult obstructive sleep apnoea syndrome. J R Col Physicians Lond. 1999;33(5):439-44.

25. Yamamoto U, Mohri M, Shimada K, Origuchi H, Miyata K, Ito K, et al Six-month aerobic exercise training ameliorates central sleep apnea in patients with chronic heart failure. J Card Fail. 2007;13(10):825-9. http://dx.doi.org/10.1016/j.cardfail.2007.08.001

26. Ueno LM, Drager LF, Rodrigues AC, Rondon MU, Braga AM, Mathias W Jr, et al. Effects of exercise training in patients with chronic heart failure and sleep apnea. Sleep. 2009;32(5):637-47.

27. Quan SF, O'Connor GT, Quan JS, Redline S, Resnick HE, Shahar E, et al. Association of physical activity with sleep-disordered breathing Sleep Breath. 2007;11(3):149-57. http://dx.doi.org/10.1007/s11325006-0095-5

28. Sengul YS, Ozalevli S, Oztura I, Itil O, Baklan B. The effect of exercise on obstructive sleep apnea: a randomized and controlled trial. Sleep Breath. 2011;15(1):49-56. http://dx.doi.org/10.1007/s11325-0090311-1

29. Awad KM, Malhotra A, Barnet JH, Quan SF, Peppard PE. Exercise is associated with a reduced incidence of sleep-disordered breathing Am J Med. 2012;125(5):485-90. http://dx.doi.org/10.1016/j. amjmed.2011.11.025

30. Giebelhaus V, Strohl KP, Lormes W, Lehmann M, Netzer N. Physical Exercise as an Adjunct Therapy in Sleep Apnea-An Open Trial. Sleep Breath. 2000;4(4):173-176

31. Fregosi RF, Ludlow CL. Activation of upper airway muscles during breathing and swallowing. J Appl Physiol (1985). 2014;116(3):291301. http://dx.doi.org/10.1152/japplphysiol.00670.2013

32. Vincent HK, Shanely RA, Stewart DJ, Demirel HA, Hamilton KL, Ray $A D$, et al. Adaptation of upper airway muscles to chronic endurance exercise. Am J Respir Crit Care Med. 2002;166(3):287-93. http:// dx.doi.org/10.1164/rccm.2104120

33. Haxhiu MA, van Lunteren E, Mitra J, Cherniack NS, Strohl KP. Comparison of the responses of the diaphragm and upper airway muscles to central stimulation of the sciatic nerve. Respir Physiol. 1984;58(1):65-76. http://dx.doi.org/10.1016/0034-5687(84)90045-8

34. Hussain SN, Ward ME, Gatensby AG, Roussos C, Deschamps A Respiratory muscle activation by limb muscle afferent stimulation in anesthetized dogs. Respir Physiol. 1991;84(2):185-98. http://dx.doi. org/10.1016/0034-5687(91)90116-Z

35. Shiota S, Ryan CM, Chiu KL, Ruttanaumpawan $\mathrm{P}$, Haight J, Arzt M et al. Alterations in upper airway cross-sectional area in response to lower body positive pressure in healthy subjects. Thorax. 2007;62(10):868-72. http://dx.doi.org/10.1136/thx.2006.071183

36. Redolfi S, Arnulf I, Pottier M, Lajou J, Koskas I, Bradley TD, et al. Attenuation of obstructive sleep apnea by compression stockings in subjects with venous insufficiency. Am J Respir Crit Care Med. 2011;184(9):1062-6. http://dx.doi.org/10.1164/rccm.201102-03500C

37. Redolfi S, Arnulf I, Pottier M, Bradley TD, Similowski T. Effects of venous compression of the legs on overnight rostral fluid shift and obstructive sleep apnea. Respir Physiol Neurobiol. 2011;175(3):390-
3. http://dx.doi.org/10.1016/j.resp.2011.01.001

38. White LH, Bradley TD. Role of nocturnal rostral fluid shift in the pathogenesis of obstructive and central sleep apnoea. J Physiol. 2013;591(5):1179-93. http://dx.doi.org/10.1113/ jphysiol.2012.245159

39. Mirrakhimov AE. Physical exercise related improvement in obstructive sleep apnea. Look for the rostral fluid shift. Med Hypotheses. 2013:80(2):125-8. http://dx.doi.org/10.1016/j. mehy.2012.11.007

40. Redolfi S, Yumino D, Ruttanaumpawan P, Yau B, Su MC, Lam J, et al. Relationship between overnight rostral fluid shift and Obstructive Sleep Apnea in nonobese men. Am J Respir Crit Care Med. 2009;179(3):241-6. http://dx.doi.org/10.1164/rccm.200807-10760C

41. White LH, Lyons OD, Yadollahi A, Ryan CM, Bradley TD. Effect of below-the-knee compression stockings on severity of obstructive sleep apnea. Sleep Med. 2015;16(2):258-64. http://dx.doi. org/10.1016/j.sleep.2014.12.005

42. Mendelson M, Lyons OD, Yadollahi A, Inami T, Oh P, Bradley TD. Effects of exercise training on sleep apnoea in patients with coronary artery disease: a randomised trial. Eur Respir J. 2016:48(1):142-50. http://dx.doi.org/10.1183/13993003.01897-2015

43. Beltrami FG, Nguyen X, Pichereau C, Maury E, Fleury B, Fagondes S. Sleep in the intensive care unit. J Bras Pneumol. 2015;41(6):539-46. http://dx.doi.org/10.1590/S1806-37562015000000056

44. Ratnavadivel R, Chau N, Stadler D, Yeo A, McEvoy RD, Catcheside PG. Marked reduction in obstructive sleep apnea severity in slow wave sleep. J Clin Sleep Med. 2009;5(6):519-24

45. McSharry DG, Saboisky JP, Deyoung P, Matteis P, Jordan AS Trinder $\mathrm{J}$, et al. A mechanism for upper airway stability during slow wave sleep. Sleep. 2013;36(4):555-63. http://dx.doi.org/10.5665/ sleep. 2544

46. Heinzelmann F, Bagley RW. Response to physical activity programs and their effects on health behavior. Public Health Rep. 1970;85(10):905-11. http://dx.doi.org/10.2307/4594000

47. Martins PJ, Mello MT, Tufik S. Exercício e Sono. Rev Bras Med Esporte. 2001;7(1):28-36.

48. Youngstedt SD, O'Connor PJ, Crabbe JB, Dishman RK. The influence of acute exercise on sleep following high caffeine intake. Physiol Behav. 2000;68(4):563-70. http://dx.doi.org/10.1016/S0031 9384(99)00213-9

49. Youngstedt SD, O'Connor PJ, Dishman RK. The effects of acute exercise on sleep: a quantitative synthesis. Sleep. 1997;20(3):20314.

50. Kredlow MA, Capozzoli MC, Hearon BA, Calkins AW, Otto MW The effects of physical activity on sleep: a meta-analytic review. $J$ Behav Med. 2015;38(3):427-49. http://dx.doi.org/10.1007/s10865015-9617-6

51. Newman AB, Foster G, Givelber R, Nieto FJ, Redline S, Young T. Progression and regression of sleep-disordered breathing with changes in weight: the Sleep Heart Health Study. Arch Intern Med. 2005;165(20):2408-13. http://dx.doi.org/10.1001/ archinte.165.20.2408

52. Dobrosielski DA, Patil S, Schwartz AR, Bandeen-Roche K, Stewart KJ. Effects of exercise and weight loss in older adults with obstructive sleep apnea. Med Sci Sports Exerc. 2015;47(1):20-6. http://dx.doi.org/10.1249/MSS.0000000000000387

53. Barnes M, Goldsworthy UR, Cary BA, Hill CJ. A diet and exercise program to improve clinical outcomes in patients with obstructive sleep apnea - a feasibility study. J Clin Sleep Med. 2009;5(5):409-15.

54. Alves Eda S, Ackel-D'Elia C, Luz GP, Cunha TC, Carneiro G, Tufik S et al. Does physical exercise reduce excessive daytime sleepiness by improving inflammatory profiles in obstructive sleep apnea patients? Sleep Breath. 2013;17(2):505-10. http://dx.doi.org/10.1007/ s11325-012-0729-8

55. Cavagnolli DA, Esteves AM, Ackel-D'Elia C, Maeda MY, de Faria AP, Tufik S, et al. Aerobic exercise does not change $\mathrm{C}$-reactive protein levels in non-obese patients with obstructive sleep apnoea. Eur $J$ Sport Sci. 2014;14 Suppl 1:S142-7.

56. Norman JF, Von Essen SG, Fuchs RH, McElligott M. Exercise training effect on obstructive sleep apnea syndrome. Sleep Res Online. 2000;3(3):121-9.

57. Kline CE, Crowley EP, Ewing GB, Burch JB, Blair SN, Durstine JL, et al. The effect of exercise training on obstructive sleep apnea and sleep quality: a randomized controlled trial. Sleep. 2011;34(12):163140. http://dx.doi.org/10.5665/sleep.1422

58. Servantes DM, Pelcerman A, Salvetti XM, Salles AF, de Albuquerque 
PF, de Salles FC, et al. Effects of home-based exercise training for patients with chronic heart failure and sleep apnoea: a randomized comparison of two different programmes. Clin Rehabil. 2012;26(1):45-57. http://dx.doi.org/10.1177/0269215511403941

59. Aiello KD, Caughey WG, Nelluri B, Sharma A, Mookadam F, Mookadam M. Effect of exercise training on sleep apnea: A systematic review and meta-analysis. Respir Med. 2016;116:85-92. http://dx.doi.org/10.1016/j.rmed.2016.05.015

60. Ackel-D'Elia C, da Silva AC, Silva RS, Truksinas E, Sousa BS, Tufik
S, et al., Effects of exercise training associated with continuous positive airway pressure treatment in patients with obstructive sleep apnea syndrome. Sleep Breath. 2012;16(3):723-35. http://dx.doi. org/10.1007/s11325-011-0567-0

61. Schütz TC, Cunha TC, Moura-Guimaraes T, Luz GP, Ackel-D’Elia C, Alves Eda $\mathrm{S}$, et al. Comparison of the effects of continuous positive airway pressure, oral appliance and exercise training in obstructive sleep apnea syndrome. Clinics (Sao Paulo). 2013;68(8):1168-74. http://dx.doi.org/10.6061/clinics/2013(08)17 